\title{
Easy preparation of graphite-containing gel electrolytes using a gelator and characterization of their electrochemical properties
}

\author{
Zhong Wang $^{\mathrm{a}}$, Seiya Fujisawa ${ }^{\mathrm{b}}$, Masahiro Suzuki ${ }^{\mathrm{b}}$, Kenji Hanabusa ${ }^{\mathrm{a}, \mathrm{b}}$
}

\author{
a Institute for Fiber Engineering, ICCER, Shinshu University, Ueda, 386-8567, Japan \\ b Interdisciplinary Graduate School of Science and Technology, Shinshu University, \\ Ueda, 386-8567, Japan
}

\begin{abstract}
Cyclo(L- $\beta$-3,7-dimethyloctylasparaginyl-L-phenylalanyl) was used as a gelator to synthesize gel electrolytes using 1-butyl-3-methylimidazolium tetrafluoroborate, propylene carbonate, and $\gamma$-butyrolactone in $1 \mathrm{M} \mathrm{LiBF}_{4}$. Gel strengths and thermal stabilities were studied with regard to the effect of graphite as a helper additive. Ionic conductivities, activation energies for ionic conductivity, and the electrochemical stabilities of the graphite-containing gel electrolytes were studied.
\end{abstract}

Key words: gel, gelator, ionic conductivity, graphite, gel electrolyte

\section{Introduction}

According to the definition by Flory, a substance is a gel if it has a continuous structure that exhibits solid-like rheological behavior and has permanent macroscopic dimensions throughout the duration of an analytical experiment (1). Gels can be classified into two types, chemical and physical gels. Chemical gels are generally characterized by a three-dimensional (3D) network structure with covalent bonds, and the most distinguished examples of chemical gels the superabsorbent polymers and soft contact lenses. Physical gels are characterized by dynamic cross-links that are constantly created and broken so that the gel changes its state between solid and liquid under the influence of environmental factors (2). Low-molecular-weight gelators (LMWGs) have captured great attention because of their singular properties and potential applications as soft materials in several fields. LMWGs, which have been 
reported by many outstanding books and reviews (3-7), usually form self-assembled gels through noncovalent forces such as hydrogen bonding, van der Waals force, $\pi-\pi$ stacking, and electrostatic interactions. LMWGs can comprise numerous nanostructures, such as nanofibers, nanoribbons, nanosheets, nanoparticles, helices, and bundle structures. In this regard, LMWGs are characterized by their ability to form several types of nanostructure in suitable solvents (8).

A key component in lithium-ion batteries is the electrolyte. Traditional lithium-ion batteries use polar solvents and lithium ions as the electrolyte, thus providing advantages such as high conductivity, low cost, high ion-transport speed, and long cycle life. However, some challenges, such as leakage and inflammability, exist that limit their possible applications. Solid electrolytes have also played an important role in solid-state batteries because they offer higher energy density than traditional electrolytes in normal lithium-ion batteries. However, the problems of stability, mechanical strength, cost, and environmental influences have not yet been solved satisfactorily. With regard to the shortcomings of traditional electrolytes, gel electrolytes have been widely studied. Gel electrolytes are materials that combine the properties of both liquid and solid electrolytes. They do not contain an inflammable liquid electrolyte and thus can improve the safety performance of lithium-ion batteries while providing the conductivity of liquid electrolytes (10-14). As they exhibit a conductivity similar to that of liquid electrolytes, many gel polymers such as poly(ethylene oxide) $(9,10)$, poly(vinylidene fluoride) (11), poly(methyl methacrylate) $(12,13)$, and polyacrylonitrile (14) have been widely reported. Apart from these, some LMWGs have been used to convert liquid electrolytes for lithium-ion batteries to gel via the formation of 3D fibrous networks through intermolecular interactions such as hydrogen bonding and van der Waals force. For example, Yanagida et al. used 1-hexyl3-methylimidazolium iodide, iodine, and an L-isoleucine-based LMWG to fabricate quasi-solid-state dye-sensitized solar cells (DSCs) with high stability and good performance (15). Sun et al. synthesized 1,3:2,4-di-O-dimethylbenzylidene-D-sorbitol prepared from D-sorbitol and 3,4-dimethylbenzaldehyde, which formed a gel with good charge-discharge characteristics in $\mathrm{KOH}$ aqueous solution (16). Basrur et al. combined 
1,3:2,4-di-O-methylbenzylidene-D-sorbitol as a LMWG with fumed silica to prepare a gel electrolyte using $\mathrm{LiClO}_{4}$ and propylene carbonate (17). Li et al. reported a series of LMWGs of $N$-Boc-D-glutamic ester derivatives that can gel the commercial liquid electrolyte for lithium-ion batteries and broaden their electrochemical window (18).

In this study, we focused on L- $\beta$-3,7-dimethyloctylasparaginyl-L-phenylalanyl (19) as a LMWG, which can be used to synthesize gels with ionic liquids as well as organic solvents. We prepared gels using 1-butyl-3-methylimidazolium tetrafluoroborate ((bmim)BF 4$)$, propylene carbonate (PC), and $\gamma$-butyrolactone $(\gamma-\mathrm{BL})$ in $1 \mathrm{M} \mathrm{LiBF}_{4}$, which contained graphite as a helper additive. Gelation behaviors, gel strengths, thermal stabilities, and electrochemical properties of the gel electrolytes were studied with regard to the effect of graphite.

\section{Experimental}

\section{Material}

Cyclo(L- $\beta$-3,7-dimethyloctylasparaginyl-L-phenylalanyl) was prepared according to the literature (19). PC and $\mathrm{LiBF}_{4}$ were purchased from TCI. Graphite, $\gamma$-BL, and (bmim)BF 4 were from purchased Wako Pure Chemical Ltd.

\section{Gelation evaluation}

The gelation test was performed using a test-tube upside-down method. A sample was dissolved in a solvent by heating and then the mixture was cooled to $25^{\circ} \mathrm{C}$ for $2 \mathrm{~h}$ in a temperature-controlled chamber. When no fluid ran down the wall of the test tube upon inversion of the tube, we judged it to be a gel.

\section{TEM observations}

Transmission electron microscopy (TEM) was performed using a JEOL-2010 electron microscope at a voltage of $200 \mathrm{kV}$. The samples were prepared at a concentration below the minimum gelation concentration, and then dropped on a grid that had a carbon film attached to it. After drying in vacuum for 2-3 days, the samples were stained with osmium tetroxide over one night.

\section{Electrochemical measurements}

Ionic conductivity and cyclic voltammograms (CVs) were measured using a Solartron 
SI 1287 electrochemical interface from TOYO Corporation. A 0.27-cm-thick Teflon plant with a hole radius of $0.3 \mathrm{~cm}$ was adhered with insulation tape on both sides. The gelator was dissolved in $1 \mathrm{~mL}$ of PC or $\gamma$-BL dissolved in $1 \mathrm{M} \mathrm{LiBF}_{4}$, and a weighed portion of graphite was added. After heating, the sample was filled in the hole of the Teflon plant. The Teflon plant was then sandwiched between two pieces of ITO electrodes and placed in an oven at $25^{\circ} \mathrm{C}$ for $2 \mathrm{~h}$.

\section{Results and Discussion}

\section{Gelation behavior}

Strong gelation abilities have so far been found in a family of amino-acid derivatives, and the application of these substances in gel electrolytes was reported (20). In this study, we studied cyclo(L- $\beta$-3,7-dimethyloctylasparaginyl-L-phenylalanyl) (1) (Figure 1) because (a) it can be easily prepared in moderate yield from "aspartame," which is an artificial sweetener and (b) it can gel most ionic liquids (19) as well as high polar solvents (21). We studied the gelation behavior of graphite-containing (bmim)BF 4 , $\mathrm{LiBF}_{4} / \mathrm{PC}$, and $\mathrm{LiBF}_{4} / \gamma$-BL. The results of the gelation tests are summarized in Table 1. One-milliliter samples of solutions containing the sole components (bmim)BF4, PC, and $\gamma$-BL without graphite were gelled by adding 10,10 , and $40 \mathrm{mg}$, respectively, of gelator 1. In contrast, solutions of $1 \mathrm{M} \mathrm{LiBF}_{4} / \mathrm{PC}$ and $1 \mathrm{M} \mathrm{LiBF}_{4} / \gamma-\mathrm{BL}$ could not be gelled even by adding $100 \mathrm{mg}$ of $\mathbf{1}$. This result can be explained by the increasing dielectric constants of PC and $\gamma$-BL by adding $\mathrm{LiBF}_{4}$. Although we failed in gelling 1 $\mathrm{M} \mathrm{LiBF}_{4} / \mathrm{PC}$ and $1 \mathrm{M} \mathrm{LiBF}_{4} / \gamma-\mathrm{BL}$, we succeeded in gelling them using graphite (particle size $\sim 45 \mu \mathrm{m}$ ) as a helper additive. Figure 2 shows photos of the gels of graphite-containing $\mathrm{LiBF}_{4} / \mathrm{PC}$ prepared by cooling the warm solutions of $1 \mathrm{M}$ $\mathrm{LiBF}_{4} / \mathrm{PC}$ containing graphite and $100 \mathrm{mg}$ of 1 under ultrasonic irradiation. Notably, ultrasonic irradiation was indispensable for the formation of gels with homogeneously dispersed graphite. Figure 2 also shows the appearance of a precipitate from the solution of $1 \mathrm{M} \mathrm{LiBF}_{4} / \mathrm{PC}$ containing $100 \mathrm{mg}$ of $\mathbf{1}$. The precipitation of 1 from $\mathrm{LiBF}_{4} / \mathrm{PC}$ and $\mathrm{LiBF}_{4} / \gamma-\mathrm{BL}$ suggests that there is a delicate balance between gelation and crystallization. The reason for this is that both gelation and crystallization occur as a 
result of cooperating noncovalent interactions such as hydrogen bonding and van der Waals forces. The progression from small aggregates of $\mathbf{1}$ to crystal-like large ones is assumed to accelerate in high polar solvents containing $\mathrm{LiBF}_{4}$. Dispersed graphite in $\mathrm{LiBF}_{4} / \mathrm{PC}$ and $\mathrm{LiBF}_{4} / \gamma$-BL prevents this excessive aggregation and consequently form stable gels.

IR spectra provide important information on hydrogen-bond formation. We measured the FT-IR spectra of precipitates from a solution of $\mathrm{LiBF}_{4} / \mathrm{PC}$, a gel of PC, a gel of graphite-containing $\mathrm{LiBF}_{4} / \mathrm{PC}$, and a chloroform isotropic solution of $\mathbf{1}$. In the spectrum of the precipitate, PC gel, and graphite-containing gel, the band at $3329 \mathrm{~cm}^{-1}$ was assigned to $\mathrm{N}-\mathrm{H}$ hydrogen-bonding stretching vibrations. In contrast, the spectrum of the isotropic solution of $\mathbf{1}$ in chloroform showed $\mathrm{N}-\mathrm{H}$ stretching vibration at 3382 $\mathrm{cm}^{-1}$, which indicates no hydrogen bonding. The FT-IR results suggest that hydrogen bonding among amide plays a vital role in the gelation process regardless of the presence of graphite, and hydrogen bonding works as a driving force for both precipitation and gelation.

The effect of graphite on the 3D networks formed by $\mathbf{1}$ was studied by TEM. Figure 3 shows TEM images of the PC gel without graphite and graphite-containing PC gels formed by $\mathbf{1}$; they show fine thread-like aggregates with nearly homogeneous diameters. The aggregate diameters for the PC gel without graphite (Figure 3a) and for that containing $2.5 \mathrm{mg} / \mathrm{mL}$ graphite (Figure $3 \mathrm{~b}$ ) are $150 \mathrm{~nm}$. However, when $10 \mathrm{mg}$ of graphite was added to $1 \mathrm{~mL}$ of PC, the diameter decreased to $\sim 50 \mathrm{~nm}$ (Figure 3c). We expect that the dispersed graphite in $\mathrm{LiBF}_{4} / \mathrm{PC}$ and $\mathrm{LiBF}_{4} / \gamma-\mathrm{BL}$ works as a wall, preventing excessive aggregation so that slender fibers are formed.

\section{Gel strength and thermal stability}

Gel strength, which is an important parameter in gel applications, is often evaluated by measuring the elastic storage modulus $G^{\prime}$ and loss modulus $G^{\prime \prime}$. However, in this study, we evaluated the gel strength as the force required to sink a cylindrical bar (10 mm in diameter) 4-mm deep in the gels. In general, gel strength increases nearly in proportion to the added amount of gelator $(19,20)$. Increasing the gel strength was also observed in the PC gels prepared using $\mathbf{1}$ (Figure S1); for instance, the strengths of PC gels 
prepared at 20 and $100 \mathrm{mg} / \mathrm{mL}$ (1/PC) were ca. 250 and $4160 \mathrm{~g} \mathrm{~cm}^{-2}$ at $25{ }^{\circ} \mathrm{C}$, respectively. The trend of increasing the gel strength with increasing gelator amount is reasonable because a higher concentration of $\mathbf{1}$ would lead to the formation of dense 3D networks.

The gel strengths of graphite-containing (bmim) $\mathrm{BF}_{4}, \mathrm{PC}$, and $\mathrm{LiBF}_{4} / \mathrm{PC}$ gels were plotted against the amount of graphite added (Figure 4). The gel strength of graphitecontaining (bmim)BF 4 , comprising $50 \mathrm{mg}$ of 1 and $1 \mathrm{~mL}$ of (bmim)BF $\mathrm{BF}_{4}$, was more than $\sim 1700 \mathrm{~g} \mathrm{~cm}^{-2}$ and increased slightly with increasing amount of graphite. The graphitecontaining PC gels prepared from $100 \mathrm{mg}$ of $\mathbf{1}$ and $1 \mathrm{~mL}$ of PC were very hard, and their strength was higher than $\sim 3600 \mathrm{~g} \mathrm{~cm}^{-2}$. In contrast, the strength of the graphitecontaining $\mathrm{LiBF}_{4} / \mathrm{PC}$ gels was very low $\left(\sim 1000 \mathrm{~g} \mathrm{~cm}^{-2}\right)$ even when $200 \mathrm{mg}$ of graphite was added. This suggests that the addition of graphite only had a slight effect on gel strength.

The gels synthesized in this study show a thermally reversible sol-to-gel transition because the 3D networks responsible for gelation are constructed by noncovalent interactions. The gel-to-sol phase-transition temperature increases with increasing concentration of $\mathbf{1}$. For instance, the phase-transition temperatures of PC gels prepared at 20, 50, and $100 \mathrm{mg} / \mathrm{mL}(\mathbf{1} / \mathrm{PC})$ were $~ 50,70$, and $90{ }^{\circ} \mathrm{C}$, respectively (Figure S2). We studied the effect of graphite on the phase-transition temperatures of (bmim)BF 4 and PC gels. Figure 5 shows the phase-transition temperatures of graphite-containing (bmim)BF 4 , PC, and $\mathrm{LiBF}_{4} / \mathrm{PC}$ gels. The temperatures of the gel-to-sol phase transition for gels prepared at concentrations of $50 \mathrm{mg} \mathrm{mL}^{-1}\left(\mathbf{1} /\left(\mathrm{bmim} \mathrm{BF}_{4}\right)\right.$ and $100 \mathrm{mg} \mathrm{mL}^{-1}$ (1/PC) were $\sim 123$ and $\sim 90{ }^{\circ} \mathrm{C}$, respectively. It is clear from Figure 5 that the phasetransition temperature of gels is almost independent of the amount of added graphite; in other words, the hydrogen-bonding and van der Waals forces as main driving forces for gelation are not affected by graphite. The temperature of the gel-to-sol transition of graphite-containing $\mathrm{LiBF}_{4} / \mathrm{PC}$ was observed to be $\sim 50{ }^{\circ} \mathrm{C}$, which was low compared with that of graphite-containing PC without $\mathrm{LiBF}_{4}\left(\sim 90{ }^{\circ} \mathrm{C}\right)$. The low transition temperature of graphite-containing $\mathrm{LiBF}_{4} / \mathrm{PC}$ can probably be attributed to the high polarity of PC containing $1 \mathrm{M} \mathrm{LiBF}_{4}$. 


\section{Electrochemical properties}

Solid electrolytes, which are electrically conductive solids with ionic carriers, are becoming increasingly important because of their potential use in the fields of solidstate batteries, fuel cells, energy storage, and chemical sensors (22-25). Gelation of ionic liquids by a gelator is a conventional method for synthesizing gel electrolytes and recently, the use of thermal scanning conductometry (TSC) was reported in situ studies of the conductivity properties, reversibility, and reproducibility of the ionogels based on LMWG (26). The ionic conductivities of graphite-containing (bmim) $\mathrm{BF}_{4}$ gels compared with that of pure (bmim)BF $\mathrm{BF}_{4}$ are summarized in Table 2, for which the concentration of gelator $\mathbf{1}$ for synthesizing the gels was maintained at $50 \mathrm{mg} \mathrm{mL}^{-1}$ and the particle size of graphite was $\sim 45 \mu \mathrm{m}$. All the ionic conductivities tests were performed under the condition of $25^{\circ} \mathrm{C}$ in a temperature-controlled chamber. The ionic conductivities of pure (bmim)BF 4 and (bmim)BF 4 gel formed by $1\left(50 \mathrm{mg} \mathrm{mL}^{-1}\right)$ were 4.3 and $4.0 \mathrm{mS} \mathrm{cm}^{-1}$, respectively. Although the ionic conductivity decreased slightly owing to gelation, the ionic conductivity of (bmim)BF 4 gel was high. The result indicates that the gelator molecules hardly interfere with the mobilities of (bmim) ${ }^{+}$and $\mathrm{BF}_{4}^{-}$as ion carriers. The conductivities of graphite-containing (bmim)BF $\mathrm{BF}_{4}$ gels increased with increasing the amount of added graphite; for instance, the conductivities of (bmim)BF 4 gels containing 100 and $200 \mathrm{mg}$ of graphite were 6.1 and $9.0 \mathrm{mS} \mathrm{cm}^{-1}$, respectively. The definite reason for the increase in ionic conductivity upon adding graphite is unclear; however, we presume that the dissociation of (bmim) $\mathrm{BF}_{4}$ was accelerated by the $\pi$-electrons of graphite. The electronic contribution from graphite in itself will be ignored, because the dispersed graphite particles are isolated in the formed gel and they do not contact with each other.

The ionic conductivities of $1 \mathrm{M} \mathrm{LiBF}_{4} / \mathrm{PC}$ and graphite-containing $\mathrm{LiBF}_{4} / \mathrm{PC}$ gels are summarized in Table 3, for which the concentration of gelator $\mathbf{1}$ for synthesizing the gels was maintained at $100 \mathrm{mg} \mathrm{mL}^{-1}$. The ionic conductivity of $1 \mathrm{M} \mathrm{LiBF}_{4} / \mathrm{PC}$ was 4.0

$\mathrm{mS} \mathrm{cm}{ }^{-1}$, and the conductivity after gelation by 1 decreased to $3.4 \mathrm{mS} \mathrm{cm}^{-1}$. The slight depression of ionic conductivity upon gelation can be explained by the limited movement of ion carriers in the $3 \mathrm{D}$ networks in the gel. The depressed ionic 
conductivity was recovered by the addition of graphite; for example, the conductivities of $1 \mathrm{M} \mathrm{LiBF}_{4} / \mathrm{PC}$ gels containing 100 and $200 \mathrm{mg}$ of graphite were 4.4 and $7.1 \mathrm{mS} \mathrm{cm}^{-1}$, respectively. The ionic conductivities of $1 \mathrm{M} \mathrm{LiBF}_{4} / \gamma-\mathrm{BL}$ gels denoted the same tendency as that of $1 \mathrm{M} \mathrm{LiBF}_{4} / \mathrm{PC}$ gels; that is, the conductivities of $1 \mathrm{M} \mathrm{LiBF}_{4} / \gamma-\mathrm{BL}$ gels containing 100 and $200 \mathrm{mg}$ of graphite were 4.5 and $7.7 \mathrm{mS} \mathrm{cm}^{-1}$, respectively. We also studied the effect of silica gel (particle size $75-150 \mu \mathrm{m}$ ) as a helper additive instead of graphite with the expectation that the silica gel, which comprises polar particles, will accelerate the dissociation of $\mathrm{LiBF}_{4}$ and consequently increase the ionic conductivity. We succeeded in the physical gelation of $1 \mathrm{M} \mathrm{LiBF}_{4} / \mathrm{PC}$ with the help of silica gel and confirmed the almost similar behavior of the silica-gel-containing gels to the graphite-containing $\mathrm{LiBF}_{4} / \mathrm{PC}$ gels in terms of gel strength and thermal stability. However, the ionic conductivity was not recovered by adding silica gel; for instance, the conductivities of $1 \mathrm{M} \mathrm{LiBF}_{4} / \mathrm{PC}$ gels containing 50 and $200 \mathrm{mg}$ of silica gel were 2.3 and $2.2 \mathrm{mS} \mathrm{cm}{ }^{-1}$, respectively. The observation that the silica gel had no effect on increasing the ionic conductivity underlines the importance of the $\pi$-electrons of graphite for increasing ionic conductivity. Namely, the $\pi$-electrons of graphite would contribute to the additional charge carriers in the gel.

The temperature dependence of ionic conductivity was studied for graphitecontaining (bmim) $\mathrm{BF}_{4}$ and $\mathrm{LiBF}_{4} / \mathrm{PC}$ gels. Plots of the logarithm of conductivity against $1 / T$ for the graphite-containing (bmim) $\mathrm{BF}_{4}$ and $\mathrm{LiBF}_{4} / \mathrm{PC}$ gels were straight lines between $2.83 \times 10^{-3}$ and $3.25 \times 10^{-3} T^{-1}$ (Figure 6), suggesting that the temperature dependence obeyed the classical Arrhenius plot. The activation energies calculated using the Arrhenius equation are summarized in Table 3. The activation energy of the precipitate of $1 \mathrm{M} \mathrm{LiBF}_{4} / \mathrm{PC}$ containing $100 \mathrm{mg}$ of 1 was $8.1 \mathrm{~kJ} \mathrm{~mol}^{-1}$, which was greater than that of $1 \mathrm{M} \mathrm{LiBF}_{4} / \mathrm{PC}$ solution $\left(11.4 \mathrm{~kJ} \mathrm{~mol}^{-1}\right)$. However, the activation energies of graphite-containing $\mathrm{LiBF}_{4} / \mathrm{PC}$ gels decreased with increasing the amounts of added graphite. Finally, the activation energy of $1 \mathrm{M} \mathrm{LiBF}_{4} / \mathrm{PC}$ gel containing 200 mg of graphite decreased to $5.2 \mathrm{~kJ} \mathrm{~mol}^{-1}$. The decrease in activation energy along with the addition of graphite can be explained by the accelerated dissociation of $\mathrm{LiBF}_{4}$ and the increase of carrier mobility, which are probably caused by the $\pi$-electrons of 
graphite. Notably, the activation energies of silica-gel-containing $\mathrm{LiBF}_{4} / \mathrm{PC}$ gels were constant, independent of the added silica gel.

Electrochemical stability is a fundamental requirement for applications in electrochemical devices because it determines the highest working potential of the battery. We studied the $\mathrm{CV}$ of the $1 \mathrm{M} \mathrm{LiBF}_{4} / \mathrm{PC}$ solution and $1 \mathrm{M} \mathrm{LiBF} / \mathrm{PC}$ gel containing 1 (100 mg mL ${ }^{-1}$ ) and graphite (50 $\mathrm{mg} \mathrm{mL}^{-1}$ ) (Figure S3). The current increases sharply when the free solvent components in the electrolyte decompose, and the corresponding decomposition voltage represents the upper operating limit. The decomposition voltage of the $1 \mathrm{M} \mathrm{LiBF}_{4} / \mathrm{PC}$ solution was about $5.5 \mathrm{~V}$, whereas that of graphite-containing $1 \mathrm{M} \mathrm{LiBF}_{4} / \mathrm{PC}$ gel was much higher than $8 \mathrm{~V}$. The improvement in the decomposition voltage was contributed to the 3D networks of the gel, which affect the ion transfer and stability of the free solvent molecules. Therefore, this clearly demonstrates that the graphite-containing $1 \mathrm{M} \mathrm{LiBF}_{4} / \mathrm{PC}$ gels may have potential applications for high-voltage lithium-ion batteries.

\section{Conclusions}

Gel electrolytes of (bmim)BF $4, P C$, and $\gamma$-BL were easily obtained by adding gelator $\mathbf{1}$ to the respective solutions. Gel electrolytes of $1 \mathrm{M} \mathrm{LiBF}_{4} / \mathrm{PC}$ and $1 \mathrm{M} \mathrm{LiBF}_{4} / \gamma$-BL were obtained with the help of graphite. Hydrogen bonding among the amide bonds of $\mathbf{1}$ plays a vital role in the gelation process regardless of the presence of graphite. The effect of graphite on the 3D networks formed by 1 was studied by TEM. Fine, threadlike aggregates with nearly homogeneous diameters were observed in graphite-containing gel electrolytes. The gel strengths of graphite-containing (bmim) $\mathrm{BF}_{4}, \mathrm{PC}$, and $\mathrm{LiBF}_{4} / \mathrm{PC}$ gels increased slightly with increasing amounts of added graphite. The gelto-sol phase-transition temperatures are also almost independent of the amount of added graphite; in other words, the hydrogen-bonding and van der Waals forces as main driving forces for gelation are not affected by graphite. The ionic conductivity of (bmim) $\mathrm{BF}_{4}$ marginally decreased owing to gelation, indicating that the gelator molecules hardly interfere with the mobility of $(\mathrm{bmim})^{+}$and $\mathrm{BF}_{4}{ }^{-}$as ion carriers. The conductivities of graphite-containing (bmim) $\mathrm{BF}_{4}$ gels increased with increasing 
amounts of added graphite. The ionic conductivities of $1 \mathrm{M} \mathrm{LiBF}_{4} / \mathrm{PC}$ gels slightly decreased owing to gelation, but the depressed ionic conductivity was recovered by the addition of graphite. The increase in the ionic conductivity of the gel electrolytes using graphite as the helper additive was explained by the accelerated dissociation of (bmim)BF 4 and $\mathrm{LiBF}_{4}$ caused by the $\pi$-electrons of graphite. Activation energies for ionic conductivity were calculated from the Arrhenius equation. The activation energies of graphite-containing $\mathrm{LiBF}_{4} / \mathrm{PC}$ gels decreased with increasing amounts of added graphite. Enhanced electrochemical stability was confirmed in graphite-containing $1 \mathrm{M}$ $\mathrm{LiBF}_{4} / \mathrm{PC}$ gels.

\section{References}

1) Flory, P.J. (1974) Gels and gelling process. Faraday Discussions of the Chemical Society, 57:7-18.

2) An, Y., Solids, F.J., Jiang, H. (2010) A thermodynamic model of physical gels. Journal of the Mechanics and Physics of Solids, 58:2083-2099

3) Terech, P., Weiss, R.G. (1997) Low Molecular Mass Gelators of Organic Liquids and the Properties of Their Gels. Chemical Reviews, 97:3133-3159.

4) Estroff, L.A., Hamilton, AD. (2004) Water Gelation by Small Organic Molecules. Chemical Reviews, 104:1201-1217.

5) Sangeetha, N., Maitra, U. (2005) Supramolecular gels: Functions and uses.

Chemical Society Reviews, 34:821-836.

6) de Loos, M., Feringa, B.L., van Esch, J.H. (2005) Design and application of selfassembled low molecular weight hydrogels. European Journal of Organic Chemistry, 2005(17):3615-3631.

7) Weiss, R.G. and Terech, P. (2006) Molecular Gels: Materials with Self-assembled Fibrillar Networks; Springer-Verlag: Dordrecht, The Netherlands.

8) Suzuki, M., Hanabusa, K. (2009) L-Lysine-based low-molecular-weight gelators. Chemical Society Reviews, 38:967-975.

9) Liu, J., Xu, J., Lin, Y., Li, J., Lai, Y., Yuan, C., Zhang, J., and Zhu, K. (2013) All- 
solid-state Lithium Ion Battery: Research and Industrial Prospects. Acta Chimica Sinica, 71:869-878.

10) Li, W.J., Li, Z.H., Yang, C.L., Xiao, Q.Z., Lei, G.T., and Ding, Y.H. (2016) A capsule-type gelled polymer electrolyte for rechargeable lithium batteries. RSC Advances, 6:47833-47839.

11) Jiang, H.J., Zhang, Y.Q., Wu, D.Y., Yu, X.H. and Cao, J.H. (2015) Design and Characterization of High Performance Electrospun Separator for Lithium Ion Battery. Acta Polymerica Sinica, 11:1271-1279.

12) Ali U., Karim K.J.B.A., and Buang, N.A. (2015) A Review of the Properties and Applications of Poly(Methyl Methacrylate)(PMMA). Polymer Reviews, 55:678-705.

13) Kang, Y.I. and Moon, J.H. (2015) In situ Poly(methyl methacrylate)/Graphene Composite Gel Electrolytes for Highly Stable Dye-Sensitized Solar Cells. ChemSusChem, 8:3799-3804.

14) Choe, H.S., Carroll, B.G., Pasquariello, D.M. and Abraham, K.M. (1997) Characterization of Some Polyacrylonitrile-Based Electrolytes. Chemistry of Materials, 9:369-379

15) Kubo, W., Kitamura, T., Hanabusa, K., Wada, Y., Yanagida, S. (2002) Quasi-solidstate dye-sensitized solar cells using room temperature molten salts and a low molecular weight gelator. Chemical Communication, 2002(4):374-375.

16) Sun, S., Song, J., Shan, Z. and Feng, R. (2012) Electrochemical properties of a low molecular weight gel electrolyte for supercapacitor. Journal of Electroanalytical Chemistry, 676:1-5.

17) Basrur, V.R., Guo, J., Wang, C. and Raghavan, S.R. (2013) Synergistic Gelation of Silica Nanoparticles and a Sorbitol-Based Molecular Gelator to Yield HighlyConductive Free-Standing Gel Electrolytes. ACS Applied Materials \& Interfaces, 5:262-267.

18) Li, L., Zhang, Q., Huo, H., Zhou, J., Li, L. (2016) Glutamic acid derivatives as gelators for electrolyte of lithium ion batteries. RSC Advanced, 6:88820-88825.

19) Hanabusa, K., Fukui, H., Suzuki, M., Shirai, H. (2005) Specialist Gelator for Ionic Liquids. Langumuir, 21:10383-10390. 
20) Hanabusa, K., Hiratsuka, K., Kimura, M., Shirai, H. (1999) Easy Preparation and Useful Character of Organogel Electrolytes Based on Low Molecular Weight Gelator. Chemistry of Materials, 11:649-655.

21) Hanabusa, K., Matsumoto, M., Kimura, M., Kakehi, A., Shirai, H. (2000) Low molecular weight gelators for organic fluids, Gelation using a family of cyclo(dipeptide)s. Journal of Colloid and Interface Science, 224:231-244.

22) Bruce, P.G. (1995) Solid State Electrochemistry, Cambridge University Press: Cambridge, England.

23) Munshi, M.Z.A. (1995) Handbook of Solid State Batteries \& Capacitors; World Scientific: Singapore.

24) Balbuena, P.B.; Wang, Y. (2004) Lithium-Ion Batteries: Solid-Electrolyte Interphase; Imperial College Press: London, England.

25) Gray, F.M. (1991) Solid Polymer Electrolytes: Fundamentals and Technological Applications; VCH: Germany.

26) Bielejewski, M., Nowicka, K., Bielejewska, N., and Tritt-Goc, J. (2016) Ionic Conductivity and Thermal Properties of a Supramolecular Ionogel Made from a SugarBased Low Molecular Weight Gelator and a Quaternary Ammonium Salt Electrolyte Solution. Journal of the Electrochemical Society, 163: G187-G195. 
Table 1 . Results of gelation test at $25^{\circ} \mathrm{C}$.

\begin{tabular}{lccl}
\hline solvent $(1 \mathrm{~mL})$ & gelator $\mathbf{1} / \mathrm{mg}$ & graphite/mg & state \\
\hline (bmim)BF 4 & 10 & 0 & opaque gel \\
$\mathrm{PC}$ & 10 & 0 & translucent gel \\
$\gamma$-BL & 40 & 0 & translucent gel \\
$1 \mathrm{M} \mathrm{LiBF}_{4} / \mathrm{PC}$ & 100 & 0 & precipitation \\
$1 \mathrm{M} \mathrm{LiBF}_{4} / \gamma-\mathrm{BL}$ & 100 & 0 & precipitation \\
& & & \\
$(\mathrm{bmim}) \mathrm{BF}_{4}$ & 10 & $10-200$ & opaque gel \\
$\mathrm{PC}$ & 10 & $10-200$ & opaque gel \\
$\gamma-\mathrm{BL}_{1 \mathrm{M} \mathrm{LiBF}} / \mathrm{PC}$ & 100 & $10-200$ & opaque gel \\
$1 \mathrm{M} \mathrm{LiBF} / \gamma-\mathrm{BL}$ & 100 & $10-200$ & opaque gel \\
\hline
\end{tabular}

(bmim)BF4: 1-Butyl-3-methylimidazolium tetrafluoroborate, PC: Propylene carbonate, $\gamma$-BL: $\gamma$-Butyrolactone. The amounts of all solvents were fixed to $1 \mathrm{~mL}$ and the concentration of $\mathrm{LiBF}_{4}$ was $1.0 \mathrm{M}$. The addition amounts of graphite were 10, 50, 100, or $200 \mathrm{mg}$. 
Table 2. Ionic conductivities of pure (bmim) $\mathrm{BF}_{4}$ and graphite-containing (bmim) $\mathrm{BF}_{4}$ gels at $25^{\circ} \mathrm{C}$.

\begin{tabular}{cccccc}
\hline $\begin{array}{c}\text { (bmim)BF} \\
\mathrm{mL}\end{array}$ & $\begin{array}{c}\text { gelator } \mathbf{1} \\
\mathrm{mg}\end{array}$ & $\begin{array}{c}\text { graphite } \\
\mathrm{mg}\end{array}$ & $\begin{array}{c}\text { ionic conductivity } \\
\mathrm{mS} \mathrm{cm}^{-1}\end{array}$ & $\begin{array}{c}\text { activation } \\
\text { energy kJ mol }\end{array}$ & state \\
\hline 1 & 0 & 0 & 4.3 & 18.6 & liquid \\
1 & 50 & 0 & 4.0 & 17.8 & gel \\
1 & 50 & 10 & 5.0 & 16.0 & gel \\
1 & 50 & 50 & 5.3 & 16.3 & gel \\
1 & 50 & 100 & 6.1 & 14.6 & gel \\
1 & 50 & 200 & 9.0 & 10.7 & gel
\end{tabular}


Table 3. Ionic conductivities of $1 \mathrm{M} \mathrm{LiBF}_{4} / \mathrm{PC}$ and graphite-containing $\mathrm{LiBF}_{4} / \mathrm{PC}$ gels at $25^{\circ} \mathrm{C}$.

\begin{tabular}{cccccc}
\hline $\begin{array}{c}1 \mathrm{M} \mathrm{LiBF}_{4} / \mathrm{PC} \\
\mathrm{mL}\end{array}$ & $\begin{array}{c}\text { gelator } \mathbf{1} \\
\mathrm{mg}\end{array}$ & $\begin{array}{c}\text { graphite } \\
\mathrm{mg}\end{array}$ & $\begin{array}{c}\text { ionic conductivity } \\
\mathrm{mS} \mathrm{cm}^{-1}\end{array}$ & $\begin{array}{c}\text { activation } \\
\text { energy } \mathrm{kJ} \mathrm{mol}^{-1}\end{array}$ & state \\
\hline 1 & 0 & 0 & 4.0 & 8.1 & solution \\
1 & 100 & 0 & 3.4 & 10.2 & precipitate \\
1 & 100 & 10 & 3.4 & 9.5 & gel \\
1 & 100 & 50 & 3.7 & 9.9 & gel \\
1 & 100 & 100 & 4.4 & 8.7 & gel \\
1 & 100 & 200 & 7.1 & 5.2 & gel
\end{tabular}




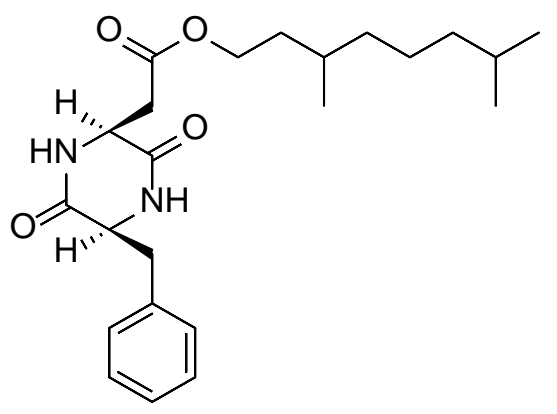

Figure 1 Chemical structure of gelator 1.



Figure 2. Photos of gels and precipitation。

Left; gel prepared from $1 \mathrm{M} \mathrm{LiBF}_{4} / \mathrm{PC}$ containing graphite and $10 \mathrm{mg}$ of graphite and $100 \mathrm{mg}$ of 1.

Middle; gel prepared from $1 \mathrm{M} \mathrm{LiBF}_{4} / \mathrm{PC}$ containing graphite and $100 \mathrm{mg}$ of graphite and $100 \mathrm{mg}$ of 1 .

Right; precipitation from $1 \mathrm{M} \mathrm{LiBF}_{4} / \mathrm{PC}$ containing $100 \mathrm{mg}$ of 1. 

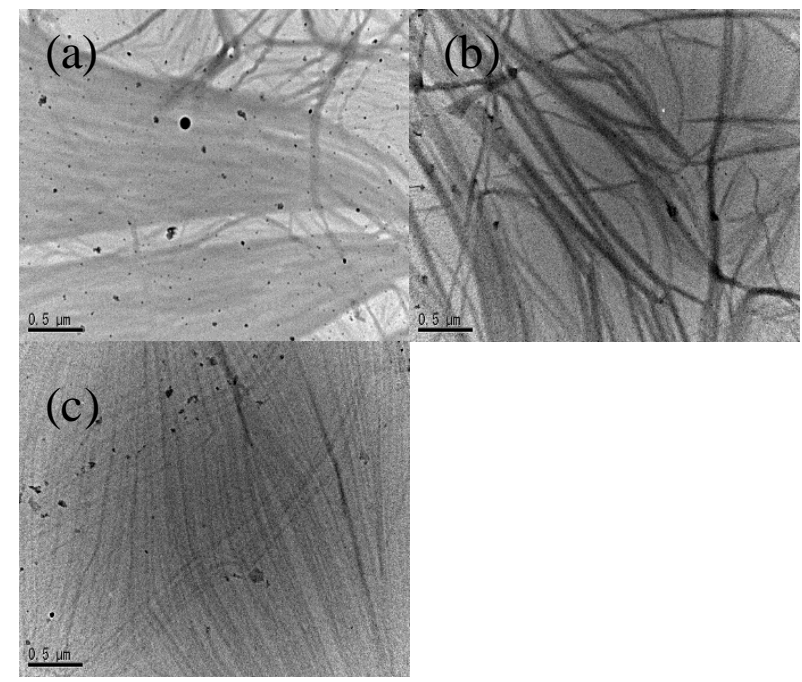

Figure 3 TEM images of PC gels.

(a); gel prepared from $5 \mathrm{mg}$ of 1 and $1 \mathrm{~mL}$ of PC.

(b); gel prepared from $2.5 \mathrm{mg}$ of graphite, $5 \mathrm{mg}$ of 1 , and $1 \mathrm{~mL}$ of PC.

(c); gel prepared from $10 \mathrm{mg}$ of graphite, $5 \mathrm{mg}$ of 1 , and $1 \mathrm{~mL}$ of PC.



Figure 4. Gel strengths of graphite-containing (bmim) $\mathrm{BF}_{4}, \mathrm{PC}$, and $\mathrm{LiBF}_{4} / \mathrm{PC}$ gels. 


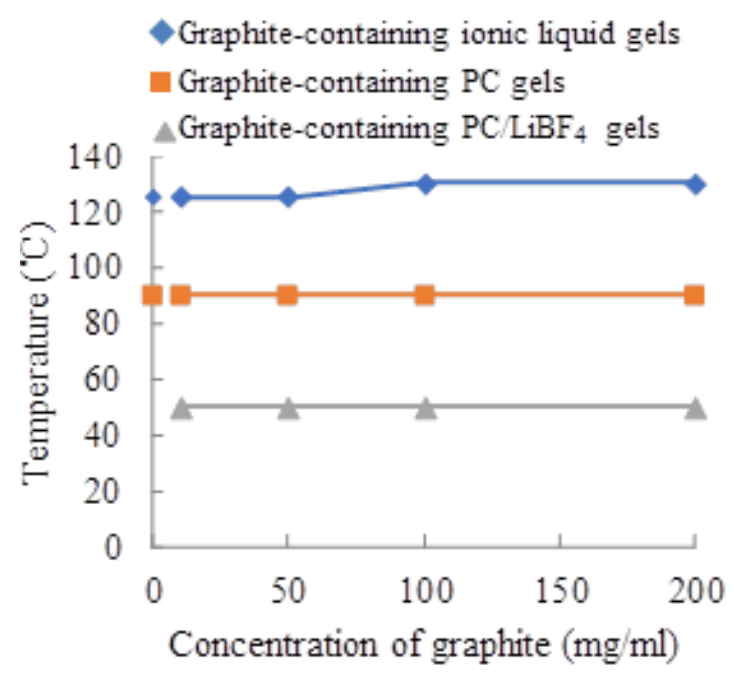

Figure 5. Gel-to-sol phase-transition temperatures of graphite-containing (bmim) $\mathrm{BF}_{4}$, $\mathrm{PC}$, and $\mathrm{LiBF}_{4} / \mathrm{PC}$ gels.

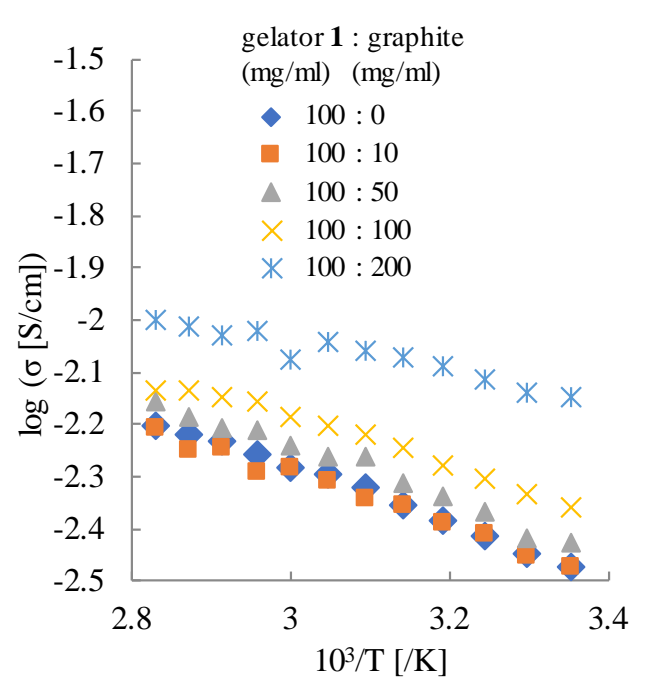

(a)



(b)

Figure 6 Temperature-dependence of ionic conductivities.

(a); graphite-containing (bmim) $\mathrm{BF}_{4}$ gels .

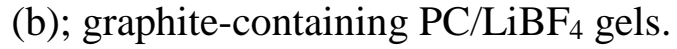

